\title{
PERANCANGAN SISTEM PENGUKURAN KINERJA PADA RUMAH SAKIT DENGAN MENGGUNAKAN METODE BALANCED SCORECARD
}

\author{
AHMAD MUBIN \\ Jurusan Teknik Industri Universitas Muhammadiyah Malang \\ Jalan Raya Tlogomas No 246 Malang \\ E-mail:mubin@umm.ac.id
}

\begin{abstract}
Elizabeth Hospital of Situbondo represent one of the some hospital exist in Sub-province of Situbondo. With condition of like this is existing hospital have to show maximal performance and can give best service to society so that can become hospital society choice. Beside give service of health, as a hospital unit also have compulsion to always ever take care of the continuity of its life, even the including all existing shares or unit to expand in an optimal fashion. With condition of above, hence company in this case RS. Elizabeth Situbondo can become company of which can exploit system measurement of performance by using method of balanced scorecard to increase company performance on an ongoing basis so that can give required service consumer swiftly is, effective, inwrought, and professional. At this research of concept which is used in designing system measurement of performance balanced scorecard. As for in perspective which used in this research cover five in perpective that is finance, cutomer or client, internal business process, study and growth, and benefit to society. From this in perpective fifth is later then developed to become performance indicators able to be measured to utilize to know level attainment of Hospital performance. Pursuant to determination of performance indicator is later then conducted measurement by using ill obtained datas from home every its indicator, this measurement use objective matrix (OMAX), where hospital periodical can do planning and control to attainment of performance. In measurement use OMAX, included also wight element of each measured indicator, where in determination of wight every the indicator use analytical hierarchy process ( AHP). In measurement of in perpective fifth conducted performance yield 23 indicator. Result of performance measurement in 2007, index attainment of performance equal to 6,616.
\end{abstract}

Key words: measurement, performance, OMAX, AHP

\section{PENDAHULUAN}

Penilaian kinerja merupakan hal yang sangat penting bagi perusahaan, karena kinerja mencerminkan peningkatan dari waktu ke waktu. Hal ini dilakukan agar perusahaan mampu bertahan dan punya daya saing. Dewasa in pengukuran kinerja secara finansial tidaklah cukup untuk mencerminkan kinerja perusahaan yang sesungguhnya. Pengukuran kinerja secara non finansialsepertikepuasan pelanggan, inovasiproduk, pengembangan perusahaan, dan pengembangan karyawannya juga harus diukur untuk menentukan kinerja perusahaan.

Kondisi seperti ini mendorong (Kaplan dan Norton, 2001) untuk menciptakan model pengukuran kinerja yang tak hanya berfokus pada aspek keuangan, yaitubalanced scorecard.Balanced scorecard berusaha untuk menerjemahkan visi, misi dan strategi perusahaan ke dalam tujuantujuan strategis, dan pengukurannya ditinjau dari empat perspektif, yaitu perspektif keuangan, perspektif pelanggan, perspektif bisnis internal, dan perspektif pembelajaran dan pertumbuhan. Selain alat pengukuran kinerja balanced scorecard juga digunakan sebagai sistem manajemen strategik untuk mengelola strategi perusahaan dalam jangka panjang (Yuwono, 2006).

Rumah Sakit (RS) Elizabeth Situbondo merupakan salah satu dari beberapa rumah sakit yang ada di Kabupaten Situbondo. Dengan kondisi seperti inilah rumah sakit yang ada harus menunjukkan kinerja yang maksimal dan mampu memberikan pelayanan yang terbaik kepada masyarakat agar dapat menjadi rumah sakit pilihan masyarakat. Di samping memberikan pelayanan kesehatan, sebagai suatu unit rumah 
sakit juga memiliki keharusan untuk selalu senantiasa menjaga kelangsungan hidupnya, bahkan termasuk semua unit atau bagian yang ada untuk berkembang secara optimal.

Dengan kondisi di atas, RS. Elizabeth Situbondo bisa memanfaatkan sistem pengukuran kinerja dengan menggunakan metode balanced scorecard untuk meningkatkan kinerja perusahaan secara berkelanjutan sehingga mampu memberikan pelayanan yang dibutuhkan konsumen dengan cepat, efektif, terpadu, dan profesional. Penelitian ini bertujuan untuk memperoleh rancangan sistem pengukuran kinerja dengan metode balanced scorecard, serta mengukur kinerja Rumah Sakit yang digunakan sebagai dasar peningkatan kinerja secara berkelanjutan.

\section{METODE}

Proses perancangan sistem pengukuran kerja dengan menggunakan metodebalanced scorecard ini pada dasarnya adalah bersifat top-down. Penetapan ukuran keberhasilan (key performance indicator) tiap prespektif adalah berdasar pada tujuan-tujuan ini merupakan hasil penjabaran dari visi, misi dan strategi perusahaan. Setiap perusahaan memiliki karakteristik dan lingkungan yang berbeda-beda, sehingga perlu dibuat langkah-langkah yang jelas dalam merancang sistem pengukuran kerja. Adapun langkah-langkah tersebut adalah sebagai berikut.

(a) Identifikasi objective strategis dan Key Performance Indicator (KPI). Pada tahap ini adalah menerjemahkan strategi yang dipilih ke dalam sasaran strategis yang komprehensif, koheren, seimbang dan terukur. Kemudian penetapan KPI haruslah sesuai dengan tujuan strategis yang telah terbangun, indikator tersebut akan menjadi parameter untuk mengukur keberhasilan tujuan strategis. Dari dokumen internal perusahaan dan dari wawancara dengan pihak manajemen yang terkait dengan masing-masing perspektif, yaitu: bidang keuangan, bagian tata usaha, bidang pelayanan medik dan keperawatan, pihak yang dianggap penting oleh peneliti untuk dijadikan narasumber.

(b) Identifikasi keterkaitan antar sasaran strategis. Pada proses ini dilakukan pengkaitan tujuan strategis untuk mengetahui hubungan yang saling mengetahui pada masing-masing tujuan strategis di setiap perspektif.

(c) Pembobotan perspektif dan KPI. Tujuan strategis dan KPI dihitung bobotnya dengan cara Analisis Hierarki Proses (AHP) pada software expert choice.

(d) Tahap perancangan sistem pengukuran kerja. Pada tahap ini terdiri dari: Penetapan target dan inisiatif. Penempatan terget ini didapat dari target perusahaan pada tahun 2006, target diperoleh daripengalaman-pengalaman perusahaan dimasa lalu atau melalui kebijakan strategis perusahaan serta mencari dan merencanakan inisiatif-inisiatif untuk masa yang akan datang. Pengukuran kinerja, langkah ini dilakukan dengan tujuan untuk mengetahui kinerja perusahaan secara komprehensif, yaitu kinerja finansial dan nonfinansial. Pengukuran ini dilakukan dengan bantuan objective matrix (OMAX).

\section{HASIL DAN PEMBAHASAN}

Berdasarkan perspektif finansial didapat objectives dan KPI sebagai berikut: Objective meningkatkan rasio profitabilitas, KPI growth rate in revenue (GRIR) dan return on investment (ROI). Menurunkan rasio hutang, dengan KPI rasio hutang. Objective meningkatkan rasio likuiditas, dengan KPI rasio lancar.

Berdasarkan visi, misi dan tujuan perusahaan yang dihubungkan dengan empat perspektif balanced scorecard dihasilkan sasaran strategi objektif rumah sakit. Strategi objektif yang telah dibahas sebelumnya selanjutnya diterjemahkan ke dalam rencana strategis yang komperhensif berdasarkan kerangka balanced scorecard. Kerangka balanced scorecard dapat dilihat pada Gambar 1.

Dari perspektif pelanggan didapat objectives dan KPI sebagai berikut: Objective meningkatkan pengunjung baru dengan KPI customer aquisition rawat jalan dan customer aquisition rawat inap. Sasaran mempertahankan dan meningkatkan kesetiaan pengunjung lama dengan KPI customer ratention. Sasaran meningkatkan mutu pelayanan dengan KPI Jumlah pelanggan komplain.

Dari perspektif proses bisnis internal didapat objectives dan KPI sebagai berikut. Sasaran meningkatkan efesiensi pengelolaan rumah sakit, 


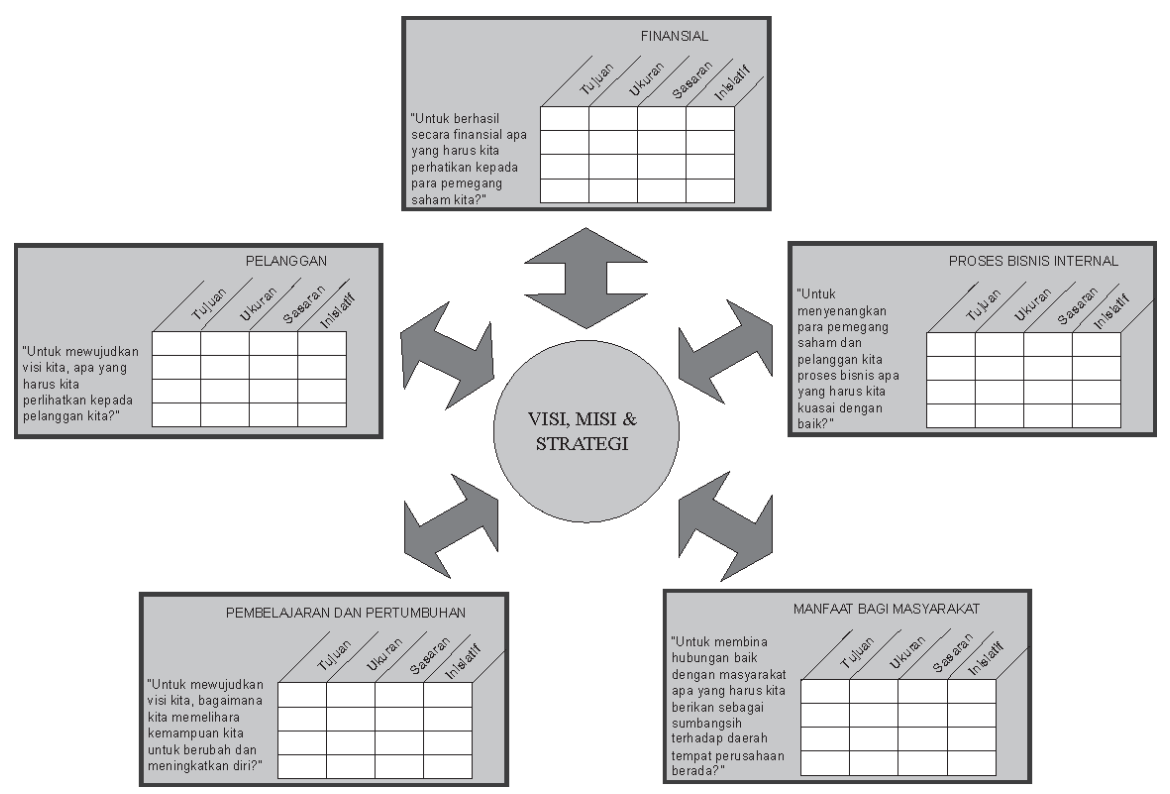

Gambar 1. Kerangka kerja balanced scorecard

dengan KPI bed occupancy rate (BOR), turn over interval (TOI), bed turn over (BTO), average length of stay (ALOS). Sasaran meningkatkan produktivitas, dengan KPI jumlah produktivitas. Sasaran meningkatkan sarana dan prasarana dengan KPI jumlah gedung VVIP dan jumlah peralatan medis.

Dari perspektif pertumbuhan dan pembelajaran dan KPI sebagai berikut. Sasaran meningkatkan loyalitas karyawan, dengan KPI employe ratention. Meningkatkan kemampuan karyawan, dengan KPI employee training. Sasaran meningkatkan kedisiplinan, dengan KPI Absensi dokter, dan absensi perawat dan pegawai nonmedis. Sasaran meningkatkan kesejahteraan karyawan, dengan KPI persentase peningkatan pendapatan. Sasaran meningkatkan keselamatan kerja dengan KPI jumlah kecelakaan kerja.

Dari perspektif manfaat bagi masyarakat dan KPI sebagai berikut. Sasaran pemberian penyuluhan kesehatan, dengan KPI Jumlah penyuluhan kesehatan. Sasaran meningkatkan perhatian di bidang pendidikan, dengan KPI jumlah mahasisiwa penelitian.

Hubungan sebab akibat antara objective dalam perspektif pada RS Elizabeth Situbondo dapat dijelaskan sebagai berikut.
Sasaran akhir yang hendak dicapai oleh RS Elizabeth Situbondo adalah meningkatkan Rasio profitabilitas dan rasio likuiditas. Rasio profitabilitas dipergunakan berhubungan dengan penilaian terhadap kinerja rumah sakit dalam menghasilkan laba. Peningkatan rasio profitabilitas diperoleh jika rumah sakit memiliki kesanggupan dalam memenuhi kewajibannya dalam hal ini menurunkan hutangnya. Untuk memenuhi target-target keuangan sebelumnya RS Elizabeth Situbondo, harus mampu meningkatkan pengunjung baru, mempertahankan dan meningkatkan kesetiaan pengunjung yang telah ada sehingga kepuasan pengunjung tetap terjaga. Hal tersebut tentu harus diperhatikan oleh rumah sakit dalam peningakatan mutu pelayanan dalam memenuhi kepuasan pengunjung.

Kemampuan perusahaan tersebut ditunjang oleh kemampuan Rumah Sakit dalam meningkatkan produktivitas, meningkatkan efesiensi pengelolaan rumah sakit serta tidak lupa juga meningkatkan saran dan prasarana. Dalam meningkatkan produktivitas sangatdipengaruhioleh meningkatnya kedisiplinan karyawan, meningkatnya loyalitas karyawan dengan tidak lupa meningkatkan keselamatan kerja karyawan. Dalam meningkatkan kedisiplinan dan loyalitas karyawan rumah 
sakit sangat ditentukan oleh meningkatnya kesejahteraan karyawan, untuk meningkatkan keselamatan kerja dipengaruhi oleh meningkatnya kemampuan para karyawan.

Rasio profitabilitas juga dipengaruhi hubungan baik rumah sakit dengan masyarakat sekitar, dengan memberikan penyuluhan kesehatan kepada masyarakat dan meningkatkan perhatian di bidang pendidikan.

Pada metode pengukuran kinerja dengan menggunakan metode balanced scorecard pengukuran awal yang dilakukan adalah membobot masing-masing perspektif, objectives dan KPI. Pembobotan dilakukan dengan menggunakan analysis hierarchy process. Saaty (1993) software expertchoice. Adapun hasilnya adalah sebagai berikut.

Perspektif finansial bobot 0,167 objectives rasio profitabilitas 0,540 , rasio hutang 0,297 dan rasio likuiditas 0,163. untuk KPI GRIR bobotnya 0,508, ROI 0,151, rasio hutang 0,265 dan rasio lancar 0,075 .

Perspektif pelanggan bobotnya 0,389 objectives meningkatkan pengunjung baru bobotnya 0,265 , mempertahankan pengunjung lama bobotnya 0,258 dan meningkatkan mutu pelayanan bobotnya 0,105. sedangkan untuk KPI customer acqusition rawat jalan bobotnya 0,265 , customer acqusition rawat inap bobotnya 0,508 , customer ratention bobotnya 0,151 , dan jumlah pelanggan komplain bobotnya 0,075 .

Perspektif proses bisnis internal bobotnya 0,277 objective meningkatkan efesiensi pengelolaan RS bobotnya 0,669, meningkatkan sarana dan prasarana bobotnya n 0,243 dan meningkatkan produktivitas bobotnya 0,088 . KPI bed occupancy rate (BOR) 0,326, turn over interval (TOI) 0,193 bed turn over (BTO) 0,166, average length of stay (ALOS) 0,125, jumlah produktivitas 0,069, jumlah gedung VVIP 0,044 dan jumlah peralatan medis 0,076 .

Perspektif pertumbuhan dan pembelajaran bobotnya 0,106 , objective meningkatkan loyalitas karyawan 0,107, meningkatkan kemampuan karyawan 0,091, meningkatkan kedisiplinan 0,581, meningkatkan kesejahteraan karyawan 0,063 dan meningkatkan keselamatan kerja 0,159.KPI ER 0,144, ET 0,0776, absensi dokter 0,356, absensi perawat dan pegawai nonmedis 0,249 , persentase peningkatan pendapatan 0,105 , dan jumlah kecelakaan kerja 0,070.

Perspektif Masyarakat 0,061, objective pemberian penyuluhan kesehatan 0,833, Meningkatkan bidang pendidikan 0,167. KPI Jumlah penyuluhan kesehatan 0,833 , dan jumlah mahasiswa penelitian 0,167 .

Berdasarkan hasil pembobotan diatas diketahui bahwa masing-masing perspektif memiliki pengaruh yang sama besar dalam kinerja rumah sakit, tetapi memiliki tingkat penyelesaian masalah yang lain dalam mengukur kinerjanya dilihat dari objectives dan key performance indicator-nya pada masing-masing perspektif, bobot yang dimiliki pada objectives dan key performance indicator.

Setelah pengobatan seluruh key performance indicator (KPI), dilakukan pembuatan Scoring System dengan menggunakan metode Objective Matrix (OMAX) yang dilakukan bersamaan dengan perancangan Traffic Light System. Scoring system diperlukan untuk mengetahui nilai pencapaian terhadap target masing-masing KPI, sedangkan Traffic Light System berfungsi sebagai tanda apakah nilai score pada suatu KPI mengindikasikan perlunya suatu perbaikan atau tidak.

Dalam Objective Matrix (OMAX) ada tiga level skor yang merupakan titik-titik utamanya yaitu: Skor 0. Merupakan nilai terburuk yang terjadi pada periode waktu tertentu. Skor 3. Merupakan nilai rata-rata yang dihitung dari tahun tertentu sampai sebelum tahun pengukuran dinilai. Skor 10. Merupakan nilai realistis yang diharapkan dapat dicapai pada tahun-tahun mendatang.

Penilaian bobot adalah menentukan tingkat kepentingan dari masing-masing key performance indicator dalam suatu perspektif (Gasperz, 2005).

Nilai performance untuk tiap-tiap key performance indicator diperoleh dari hasil perkalian antara bobot dengan skor pencapain kinerja tiaptiap perspektif.

Indeks perspektif diperoleh dengan cara menjumlahkan keseluruhan niai kinerja dalam tiap perspektif.

Adapun hasil rekapitulasi pengukuran kinerja RS. Elizabeth Situbondo tahun 2006 yang diperoleh dari pengolahan dengan menggunakan Objective Matrix (OMAX) dapat dilihat pada Tabel 1-5. 
Tabel 1. Rekapitulasi Pengukuran Kinerja Perspektif Keuangan dengan Menggunakan Objektive Matrix (OMAX)

\begin{tabular}{|c|c|c|c|c|c|c|c|c|c|}
\hline \multirow{2}{*}{ KPI } & \multirow{2}{*}{ Bobot } & \multirow{2}{*}{$\begin{array}{c}\text { Target } \\
\text { realistik }\end{array}$} & \multicolumn{3}{|c|}{ Skor Indeks Pencapaian } & \multirow{2}{*}{$\begin{array}{c}\text { Nilai } \\
\text { Tercapai }\end{array}$} & \multirow{2}{*}{ Skor } & \multirow{2}{*}{ Nilai } & \multirow{2}{*}{ Warna } \\
\hline & & & $\mathbf{0}$ & 3 & 10 & & & & \\
\hline $11 \mathrm{~A}$ & 0,508 & $37,5 \%$ & $21,94 \%$ & $27,72 \%$ & $37,5 \%$ & $36,4 \%$ & 9 & 4,572 & - \\
\hline $11 \mathrm{~B}$ & 0,151 & $28 \%$ & $1,97 \%$ & $12,74 \%$ & $28 \%$ & $27,3 \%$ & 10 & 1,510 & - \\
\hline $12 \mathrm{~A}$ & 0,265 & $2 \%$ & $9,5 \%$ & $7,32 \%$ & $2 \%$ & $3,31 \%$ & 8 & 2,12 & - \\
\hline $13 \mathrm{~A}$ & 0,075 & $600 \%$ & $188,6 \%$ & $294,5 \%$ & $600 \%$ & $577,1 \%$ & 9 & 0,675 & - \\
\hline \multicolumn{6}{|c|}{ Pencapaian Kinerja Perspektif Keuangan } & & & & \\
\hline \multicolumn{3}{|c|}{ Indeks Pencapaian Kinerja Perspektif } & \multicolumn{3}{|c|}{1,482} & & & & \\
\hline
\end{tabular}

Tabel 2. Rekapitulasi Pengukuran Kinerja Perspektif Keuangan dengan Menggunakan Objektive Matrix (OMAX)

\begin{tabular}{|c|c|c|c|c|c|c|c|c|c|}
\hline \multirow{2}{*}{ KPI } & \multirow{2}{*}{ Bobot } & \multirow{2}{*}{$\begin{array}{c}\text { Target } \\
\text { realistik }\end{array}$} & \multicolumn{3}{|c|}{ Skor Indeks Pencapaian } & \multirow{2}{*}{$\begin{array}{l}\text { Nilai } \\
\text { Tercapai }\end{array}$} & \multirow{2}{*}{ Skor } & \multirow{2}{*}{ Nilai } & \multirow{2}{*}{ Warna } \\
\hline & & & $\mathbf{0}$ & 3 & 10 & & & & \\
\hline $21 \mathrm{~A}$ & 0,265 & $47 \%$ & $46,79 \%$ & $48,44 \%$ & $47 \%$ & $45,66 \%$ & 0 & 0 & - \\
\hline $22 \mathrm{~A}$ & 0,508 & $10 \%$ & $5,7 \%$ & $15 \%$ & $10 \%$ & $7 \%$ & 6 & 3,048 & - \\
\hline $23 \mathrm{~A}$ & 0,151 & $60 \%$ & $49,88 \%$ & $51,54 \%$ & $60 \%$ & $54,33 \%$ & 5 & 0,755 & - \\
\hline $24 \mathrm{~A}$ & 0,075 & 1 & 7 & 6 & 1 & 4 & 6 & 0,45 & - \\
\hline \multicolumn{6}{|c|}{ Pencapaian Kinerja Perspektif Customer } & & & & \\
\hline \multicolumn{4}{|c|}{ Indeks Pencapaian Kinerja Perspektif } & & & & & & \\
\hline
\end{tabular}

Tabel 3. Perspektif Proses Internal Rekapitulasi Pengukuran Kinerja Bisnis dengan Menggunakan Objektive Matrix (OMAX)

\begin{tabular}{|c|c|c|c|c|c|c|c|c|c|}
\hline \multirow{2}{*}{ KPI } & \multirow{2}{*}{ Bobot } & \multirow{2}{*}{$\begin{array}{c}\text { Target } \\
\text { realistik }\end{array}$} & \multicolumn{3}{|c|}{ Skor Indeks Pencapaian } & \multirow{2}{*}{$\begin{array}{c}\text { Nilai } \\
\text { Tercapai }\end{array}$} & \multirow{2}{*}{ Skor } & \multirow{2}{*}{ Nilai } & \multirow{2}{*}{ Warna } \\
\hline & & & $\mathbf{0}$ & 3 & 10 & & & & \\
\hline $31 \mathrm{~A}$ & 0,326 & $89 \%$ & $63,89 \%$ & $72,06 \%$ & $89 \%$ & $87,98 \%$ & 9 & 2,934 & - \\
\hline $31 \mathrm{~B}$ & 0,193 & 0,5 hari & 1,91 hari & 1,34 hari & 0,5 hari & 0,52 hari & 10 & 1,93 & - \\
\hline $31 \mathrm{C}$ & 0,166 & 85 kali & $64,19 \mathrm{kali}$ & 66,3 kali & $85 \mathrm{kali}$ & $84,98 \mathrm{kali}$ & 10 & 1,66 & - \\
\hline $31 \mathrm{D}$ & 0,125 & 5 hari & 4,1 hari & 4,1hari & 5 hari & 4,35 hari & 5 & 0,625 & ? \\
\hline $32 \mathrm{~A}$ & 0,069 & 63.000 .000 & $37.124 .983,65$ & $42.649 .355,65$ & 63.000 .000 & $61.423 .006,67$ & 9 & 0,621 & - \\
\hline $33 \mathrm{~A}$ & 0,044 & 10 & 0 & 0 & 10 & 3 & 5 & 0,22 & ? \\
\hline $33 \mathrm{~B}$ & 0,076 & 80 & 26 & 40 & 80 & 72 & 8 & 0,532 & - \\
\hline \multicolumn{6}{|c|}{ Pencapaian Kinerja Perspektif Proses Bisnis Internal } & & & & \\
\hline \multicolumn{6}{|c|}{ Indeks Pencapaian Kinerja Perspektif } & & & & \\
\hline
\end{tabular}

Pada bagian ini akan dianalisis arti dari skor kinerja yang tercapai untuk masing-masing Key Performance Indicator. Sebelum analisis dilakukan perlu dijelaskan arti dari skala skor kinerja yang ada. Dalam Objective Matrix (OMAX) terdapat skala kinerja 0 sampai dengan 10. Traffic Light System akan digunakan bersamaan dengan pembuatan Objective Matrix (OMAX). Masing-masing skala kinerja dapat dijelaskan sebagai berikut. Skor 10: Kinerja sangat memuaskan. Perusahaan telah mencapai target relistis dan mempunyai inisiatif untuk meningkatkan kinerja. Skor 9-8: Kinerja memuaskan. Hampir di semua aktivitas perusahaan memperoleh hasil yang memuaskan. Perusahaan memperoleh hasil yang memuaskan. Perusahaan telah menguasai kriteria-kriteria secara konsisten. Skor 7-6: Kinerja yang dihasilkan baik. Perusahaan telah mempelajari fungsi dan kriteria (KPI) dan telah mendapatkan keahlian yang dibutuhkan untuk melaksanakan kinerja kerja dengan efektif. Skor 5-4: Kinerja yang dicapai sedang atau berada di atas standar yang ada (cukup baik). Perusahaan masih harus belajar dan mempunyai minat belajar demi peningkatan kinerja. Skor 3: Kinerja standar rata-rata. Perusahaan telah mencapai kinerja standar yang ada dan tetap dipertahankan dengan 
Tabel 4. Perspektif dan Tumbuh Rekapitulasi Pengukuran Kinerja Belajar dengan Menggunakan Objektive Matrix (OMAX)

\begin{tabular}{|c|c|c|c|c|c|c|c|c|c|}
\hline \multirow{2}{*}{ KPI } & \multirow{2}{*}{ Bobot } & \multirow{2}{*}{$\begin{array}{c}\text { Target } \\
\text { realistik }\end{array}$} & \multicolumn{3}{|c|}{ Skor Indeks Pencapaian } & \multirow{2}{*}{$\begin{array}{c}\text { Nilai } \\
\text { Tercapai }\end{array}$} & \multirow{2}{*}{ Skor } & \multirow{2}{*}{ Nilai } & \multirow{2}{*}{ Warna } \\
\hline & & & $\mathbf{0}$ & 3 & 10 & & & & \\
\hline $41 \mathrm{~A}$ & 0,144 & $0,3 \%$ & $2,51 \%$ & $1,77 \%$ & $0,3 \%$ & $0,98 \%$ & 7 & 0,747 & 8 \\
\hline $42 \mathrm{~A}$ & 0,076 & $20 \%$ & $13,6 \%$ & $14,3 \%$ & $20 \%$ & $15,3 \%$ & 4 & 0,83 & - \\
\hline $43 \mathrm{~A}$ & 0,356 & $1,9 \%$ & $3,21 \%$ & $2,91 \%$ & $1,9 \%$ & $2,1 \%$ & 9 & 0,664 & - \\
\hline $43 \mathrm{~B}$ & 0,249 & $2,3 \%$ & $3,6 \%$ & $3,52 \%$ & $2,3 \%$ & $2,5 \%$ & 9 & 0,194 & - \\
\hline $44 \mathrm{~A}$ & 0,105 & $12 \%$ & $10 \%$ & $10 \%$ & $12 \%$ & $10 \%$ & 3 & 4,55 & $\bullet$ \\
\hline $45 \mathrm{~A}$ & 0,07 & 0 & 3 & 2 & 0 & 1 & 6 & 1,04 & $\circ$ \\
\hline \multicolumn{6}{|c|}{ Pencapaian Kinerja Perspektif Belajar dan Tumbuh } & & & & \\
\hline \multicolumn{4}{|c|}{ Indeks Pencapaian Kinerja Perspektif } & 0,79 & & & & & \\
\hline
\end{tabular}

Tabel 5. Perspektif Rekapitulasi Pengukuran Kinerja Masyarakat dengan Menggunakan Objektive Matrix (OMAX)

\begin{tabular}{|c|c|c|c|c|c|c|c|c|c|}
\hline \multirow{2}{*}{ KPI } & \multirow{2}{*}{ Bobot } & \multirow{2}{*}{$\begin{array}{c}\text { Target } \\
\text { realistik }\end{array}$} & \multicolumn{3}{|c|}{ Skor Indeks Pencapaian } & \multirow{2}{*}{$\begin{array}{c}\text { Nilai } \\
\text { Tercapai }\end{array}$} & \multirow{2}{*}{ Skor } & \multirow{2}{*}{ Nilai } & \multirow{2}{*}{ Warna } \\
\hline & & & $\mathbf{0}$ & 3 & 10 & & & & \\
\hline $51 \mathrm{~A}$ & 0,833 & $70 \times$ & $30 \times$ & $39 \times$ & $70 \times$ & $50 \times$ & 6 & 4,998 & 8 \\
\hline $52 \mathrm{~A}$ & 0,167 & 20 orang & 10 & 14 & 20 & 12 & 2 & 0,334 & - \\
\hline \multicolumn{6}{|c|}{ Pencapaian Kinerja Perspektif Masyarakat } & & & & \\
\hline \multicolumn{4}{|c|}{ Indeks Pencapaian Kinerja Perspektif } & & & & & & \\
\hline \multicolumn{4}{|c|}{ Total Indeks Pencapaian Kinerja Keseluruhan } & & & & & & \\
\hline
\end{tabular}

tidak berhenti melakukan peningkatan kinerja. Skor 2-1: Kinerja yang dicapai buruk perusahaan masih berada di tingkat pemula atau dengan kata lain kinerja perusahaan berada di bawah rata-rata, masih banya yang harus dipelajari oleh peruasahaan. Skor 0: Kinerja perusahaan ditolak atau sangat buruk. Kinerja perusahaan berlawanan dengan tujuan dan sasaran key performance indikator. Perusahaan membutuhkan bimbingan yang intensif.

Sedangkan traffic light system menggunakan tiga indikator warna. Penentuan level pencapaian pada masing-masing indikator warna didasarkan pada pertimbangan pihak manajemen berkaitan dengan kemampuan perusahaan untuk memenuhi target atau sasaran strategis yang ditetapkan. Indikator warna tersebut meliputi: Warna hijau untuk level pencapiaan 8,1 sampai dengan 10 yang berarti pencapaiaan Key Performance Indikator telah sesuai dengan target yang telah ditentukan. Warna kuning, untuk level pencapaian 3,1 sampai dengan 8 yang berarti pihak manajemen harus lebih berhati-hati karena pencapaian key performance indikator belum tercapai meskipun nilainya sudah mendekati target. Warna merah, untuk level pencapaian 0 sampai dengan 3 yang berarti pencapaian key performance indikator benar-benar jauh dibawa target dan perlu diadakan perbaikan.

Selanjutnya analisis kinerja pencapaian periode tahun 2007 untuk masing-masing key performance indikator adalah sebagai berikut: KPI 11A: growth rate in revenue (GRIR) dengan skor kinerja 9 (hijau), artinya kinerja yang dicapai di atas target, ditandai dengan adanya pencapaian sebesar $36,4 \%$ dari $37,5 \%$ yang ditargetkan. KPI 11B: return on investment (ROI) dengan skor kinerja 10 (hijau), artinya kinerja yang dicapai di atas target, ditandai dengan adanya pencapaian sebesar $27,3 \%$ dari $28 \%$ yang ditargetkan. KPI 12A: rasio hutang dengan skor kinerja 8 (kuning), artinya kinerja yang dicapai baik, ditandai dengan adanya pencapaian sebesar $3,31 \%$ dari $2 \%$ yang ditargetkan. KPI 13A: rasio lancar dengan skor kinerja 9 (hijau), artinya kinerja yang dicapai di atas target, ditandai dengan adanya pencapaian sebesar $577,1 \%$ dari $600 \%$ yang ditargetkan. KPI 21A: customer acquisition instalasi rawatjalan (CA IRJA) dengan skor kinerja 0 (merah), artinya 
kinerja artinya kinerja yang dicapai benar-benar jauh di bawah target, ditandai dengan adanya pencapaian sebesar 45,66 dari 47 yang ditargetkan. KPI 22A: customer acquisition instalasi rawat inap (CA IRNA) dengan skor kinerja 6 (kuning), artinya kinerja yang dicapai baik, ditandai dengan adanya pencapaian sebesar $7 \%$ dari $10 \%$ yang ditargetkan. KPI 23A: customer retention dengan skor kinerja 5 (kuning), artinya kinerja yang dicapai baik, ditandai dengan adanya pencapaian sebesar 54,33\% dari $60 \%$ yang ditargetkan. KPI 24A: jumlah pelanggan komplain dengan skor kinerja 6 (kuning), artinya kinerja yang dicapai baik, ditandai dengan adanya pencapaian sebesar 4 dari 1 yang ditargetkan. KPI 31A: bed occupancy rate $(B O R)$ dengan kinerja 9 (hijau), artinya kinerja yang dicapai di atas target, ditandai dengan adanya pencapaian sebesar, $87,98 \%$ dari $89 \%$ yang ditargetkan. KPI 31B: turn over interval (TOI) dengan skor kinerja 10 (hijau) artinya kinerja yang dicapai di atas target, ditandai dengan adanya pencapaian sebesar 0,52 hari dari 0,5 hari yang ditargetkan. KPI 31C: bed turn over (BTO) dengan kinerja 10 (hijau), artinya kinerja yang dicapai di atas target, ditandai dengan adanya pencapaian sebesar 84,98\% dari $85 \%$ yang ditargetkan. KPI 31D: average length of stay (ALOS) dengan skor kinerja 5 (kuning), artinya kinerja yang dicapai baik, ditandai dengan adanya pencapaian sebesar 4,35 hari dari 5 hari yang ditargetkan. KPI 32A: jumlah produktivitas dengan skor kinerja 10 (hijau), artinya kinerja yang dicapai di atas target, ditandai dengan adanya pencapaian sebesar $61.423 .006,67$ dari 63.000.000 ditargetkan. KPI 33A: jumlah gedung VVIP dengan kinerja 5 (kuning), artinya kinerja yang dicapai baik, ditandai dengan adanya pencapaian sebesar 3 hari dari 10 hari yang ditargetkan. KPI 33B: jumlah peralatan medis dengan kinerja 5 (kuning), artinya kinerja yang dicapai baik, ditandai dengan adanya pencapaian sebesar 72 dari 80 yang ditargetkan. KPI 41A: employeeratention dengankinerja 7(kuning), artinya kinerja yang dicapai baik, ditandai dengan adanya pencapaian sebesar $0,98 \%$ dari 0,3 yang ditargetkan. KPI 42A: employee training kinerja 4 (kuning), artinya kinerja yang dicapai baik, ditandai dengan adanya pencapaian sebesar $15,3 \%$ dari 20 yang ditargetkan. KPI 43A: absenteesism (dokter dan dokter gigi) dengan skor kinerja 9 (hijau), artinya kinerja yang dicapai di atas target, ditandai dengan adanya pencapaian sebesar $2,1 \%$ dari 1,9\% ditargetkan. KPI 43A: absenteesism (perawat dan pegawai non medis) dengan skor kinerja 9 (hijau), artinya kinerja yang dicapai di atas target, ditandai dengan adanya pencapaian sebesar 2,5\% dari 2,3\% ditargetkan. KPI 44A: persentase peningkatan pendapatan dengan skor kinerja 3 (merah), artinya kinerja yang dicapai benar-benar jauh di bawah target, ditandai dengan adanya pencapaian sebesar $10 \%$ dari $12 \%$ yang ditargetkan. KPI 45A: jumlah kecelakaan kerja dengan skor kinerja 6 (kuning), artinya kinerja yang dicapai baik, ditandai dengan adanya pencapaian sebesar 1 dari 0 yang ditargetkan. KPI 51A: jumlah penyuluhan kesehatan dengan skor kinerja 6 (kuning), artinya kinerja yang dicapai baik, ditandai dengan adanya pencapaian sebesar 50 dari 70 yang ditargetkan. KPI 52A: jumlah mahasiswa penelitian. dengan skor kinerja 2 (merah), artinya kinerja yang dicapai benar-benar jauh di bawah target, ditandai dengan adanya pencapaian sebesar 12 orang dari 20 orang yang ditargetkan.

Berdasarkan hasil pengukuran dan penilaian kinerja tahun 2007 yang dilakukan dengan menggunakan metode OMAX, diperoleh indeks pencapaian kinerja masing-masing perspektif dan total indeks pencapaian kinerja perusahaan secara keseluruhan. Indeks pencapaian kinerja perspektif merupakan hasil perkalian antara pencapaiaan kinerja dengan bobot perspektif seperti Tabel 6 . Total Indeks pencapaian kinerja $=6,616$.

Berdasarkan hasil pengukuran dan penilaian kinerja tahun 2004-2006 yang dilakukan dengan menggunakan metode objektif matrix (OMAX) diperoleh pencapaian masing-masing perspektif.

Untuk mengetahui arti dari nilai indeks pencapaian perspektif adalah dengan cara membandingkan pencapaian perspektif dengan indeks rata-rata perspektif dan indeks target realistis perspektif.

Jika nilai dari tingkat perbaikan menunjukkan nilai yang positif, maka dapat dikatakan bahwa tercapai perbaikan yang memberikan dampak positif pada perusahaan, demikian pula sebaliknya. Berdasarkan Tabel 6 dan Gambar 2 dapat diketahui bahwa tidak ada nilai yang negatif. Semua nilai dari tingkat perbaikan menunjukkan nilai yang positif, maka dapat dikatakan bahwa tercapai 
Tabel 6. Tingkat Perbaikan

\begin{tabular}{lcccccc}
\hline \multicolumn{1}{c}{ Perspektif } & Bobot & $\begin{array}{c}\text { Kinerja } \\
\text { Pencapaian }\end{array}$ & $\begin{array}{c}\text { Kinerja } \\
\text { Rata-rata }\end{array}$ & $\begin{array}{c}\text { Indeks } \\
\text { Pencapaian }\end{array}$ & $\begin{array}{c}\text { Indeks } \\
\text { Rata-rata }\end{array}$ & $\begin{array}{c}\text { Tingkat } \\
\text { Perbaikan }\end{array}$ \\
\hline Keuangan & 0,167 & 8,877 & 3 & 1,482 & 0,501 & 1,9580 \\
Konsumen & 0,389 & 4,253 & 3 & 1,654 & 1,167 & 0,4173 \\
Proses Bisnis Internal & 0,277 & 8,522 & 3 & 2,361 & 0,831 & 1,8411 \\
Belajar dan Pertumbuhan & 0,106 & 7,492 & 3 & 0,794 & 0,318 & 1,4968 \\
Masyarakat & 0,061 & 5,3322 & 3 & 0,325 & 0,183 & 0,7759 \\
\hline
\end{tabular}

perbaikan yang memberikan dampak positif pada rumah sakit. Perspektif finansial memiliki tingkat perbaikan sebesar 1,9580 diikuti dengan perspektif proses bisnis internal memiliki tingkat perbaikan sebesar 1,8441, diikuti perspektif belajar dan pertumbuhan memiliki tingkat perbaikan sebesar 1,4968, diikuti perspektif masyarakat sebesar 0,7759 dan perspektif konsumen sebesar 0,4173

Sedangkan pada bagian ini akan ditentukan seberapa besar indeks pencapaian perspektif terhadap indeks target realisasi yang telah dicapai oleh RS. Elizabeth Situbondo selama tahun 2007.

$\frac{\text { Indeks pencapaian perspektif }}{\text { Indeks target realistis }} \times 100 \%$

Adapun untuk mengetahui tingkat pencapaian target dipergunakan rumus sebagai berikut:

Tingkat Pencapaian Target $=$ Indeks target realistis diperoleh dari perkalian jumlah bobot perspektif dengan skor kinerja tertinggi. Hasil tingkat pencapaian target dapat dilihat pada Tabel 7. Tingkat pencapaian target perspektif Finansial sebesar 8,874 yang berarti pencapaian key performance indicator

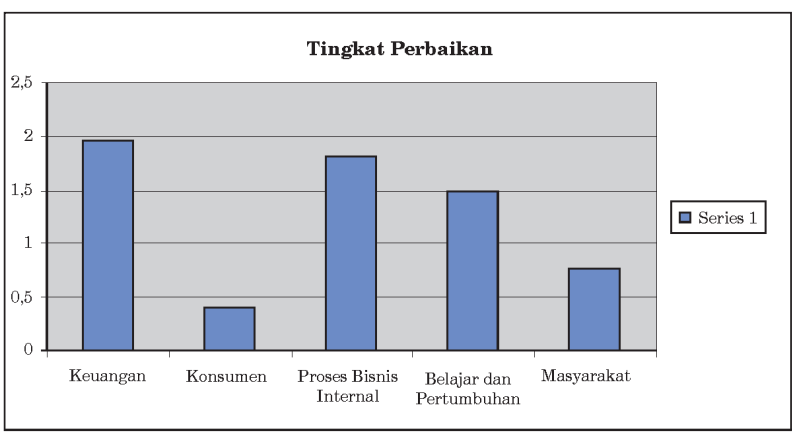

Gambar 2. Tingkat perbaikan memuaskan hampir disemua aktifitas rumah sakit. Rumah sakit telah menguasai kriteria-kriteria secara konsisten telah sesuai dengan target yang telah ditentukan. Walaupun tingkat pencapaian berada pada level memuaskan, namun rumah sakit harus dapat mempertahankan dan meningkatkan kinerjanya dalam perspektif finansial. Untuk meningkatkan kinerja finansial rumah sakit perlu memperhatikan strategi inisiatif sebagai berikut: mengurangi jumlah hutang, dan mengurangi biaya operasional.

Tingkat pencapaian target perspektif pelanggan 4,252: Kinerja yang dicapai sedang atau berada di atas standar yang ada (cukup baik). Perusahaan masih harus belajar dan mempunyai minat belajar demi peningkatan kinerja. Key performance indicator belum tercapai meskipun nilainya sudah mendekati target. Walaupun tingkat pencapaian berada di atas rata-rata, tetapi masih ada key performance indicator yang berwarna merah yaitu Meningkatkan jumlah pasien dan pengunjung baru rawat jalan: mengoptimalkan tingkat kepuasan pengunjung, dan meningkatkan mutu pelayanan.

Tingkat pencapaian target perspektif proses bisnis internal sebesar 8,523 yang berarti kinerja yangdicapai memuaskan. Hampir disemuaaktivitas perusahaan memperoleh hasil yang memuaskan. Perusahaan telah menguasai kriteria-kriteria secara konsisten. Namun rumah sakit harus dapat mempertahankan dan meningkatkan kinerjanya dalam perspektif kinerja proses bisnis internalnya rumah sakit perlu memperhatikan strategi inisiatif sebagai berikut: meningkatkan mutu pelayanan terhadap pasien, dan meningkatkan hubungan baik dengan pasien.

Tingkat pencapaian target perspektif pertumbuhan dan pembelajaran sebesar 7,490 
Tabel 7. Tingkat Pencapaian Target

\begin{tabular}{|c|c|c|c|c|c|c|}
\hline Perspektif & Bobot & $\begin{array}{c}\text { Kinerja } \\
\text { Pencapaian }\end{array}$ & $\begin{array}{c}\text { Kinerja } \\
\text { Tertinggi }\end{array}$ & $\begin{array}{c}\text { Indeks } \\
\text { Pencapaian }\end{array}$ & $\begin{array}{c}\text { Indeks } \\
\text { Target } \\
\text { Realistis }\end{array}$ & $\begin{array}{c}\text { Tingkat } \\
\text { Pencapaian } \\
\text { Target }\end{array}$ \\
\hline Keuangan & 0,167 & 8,877 & 10 & 1,482 & 1,67 & $88,74 \%$ \\
\hline Konsumen & 0,389 & 4,253 & 10 & 1,654 & 3,89 & $42,52 \%$ \\
\hline Proses Bisnis Internal & 0,277 & 8,522 & 10 & 2,361 & 2,77 & $85,23 \%$ \\
\hline Belajar dan Pertumbuhan & 0,106 & 7,492 & 10 & 0,794 & 1,06 & $74,90 \%$ \\
\hline
\end{tabular}

yang berarti kinerja Kinerja yang dihasilkan baik. Perusahaan telah mempelajari fungsi dan kriteria (KPI) dan telah mendapatkan keahlian yang dibutuhkan untuk melaksanakan kinerja kerja dengan efektif. Namun demikian rumah sakit masih harus belajar demi peningkatan kinerja. Key performance indicator belum tercapai meskipun nilainya sudah mendekati target. Walaupun tingkat pencapaian berada di atas rata-rata, tetapi masih ada key performance indicator yang berwarna merah yaitu persentase tingkat pendapatan. Untuk meningkatkan kinerja rumah sakit perlu memperhatikan strategi inisiatif sebagai berikut: pemberian reward atau bonus, dan pembayaran biaya lembur karyawan.

Tingkat pencapaian target perspektif Masyarakat sebesar 5,328 yang berarti kinerja yang dicapai berada di atas standar yang ada (cukup baik). Namun demikian rumah sakit masih harus belajar demi peningkatan kinerja. Key performance indicator belum tercapai meskipun nilainya sudah mendekati target. Walaupun tingkat pencapaian berada di atas rata-rata, tetapi masih ada key performance indicator yang berwarna merah yaitu jumlah mahasiswa penelitian. Untuk meningkatkan kinerja rumah sakit perlu memperhatikan strategi

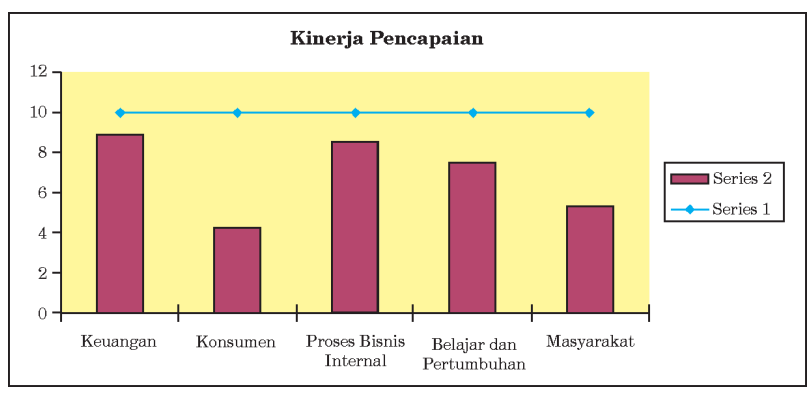

Gambar 3. Tingkat pencapaian target inisiatif sebagai berikut: meningkatkan jumlah mahasiswa yang melakukan penelitian

\section{SIMPULAN}

Berdasarkan visi, misi dan strategi rumah sakit didapatkan beberapa sasaran strategis (objectives strategic) antara lain perspektif keuangan mempunyai 3 sasaran strategis, perspektif pelanggan mempunyai 3 sasaran strategis, perspektif proses bisnis internal mempunyai 3 sasaran strategis, perspektif belajar dan pertumbuhan mempunyai 5 sasaran strategis dan Perspektif masyarakat mempunyai 2 sasaran strategis. Key performance indicator (KPI) yang ditetapkan pada RS. Elizabeth Situbondo adalah Perspektif keuangan terdapat 4 KPI, perspektif pelanggan terdapat $4 \mathrm{KPI}$, perspektif Proses bisnis internal terdapat $7 \mathrm{KPI}$, perspektif belajar dan pertumbuhan terdapat 6 KPI dan perspektif manfaat bagi masyarakat terdapat 2 KPI.

Pengukuran kinerja dengan objective matrix (OMAX) pada RS. Elizabeth Situbondo, didapatkan hasil, yaitu terdapat 9 KPI yang berwarna hijau, untuk level pencapaian 8,1 sampai dengan 10, yang berarti KPI telah sesuai dengan target yang ditentukan, terdapat 11 KPI yang berwarna kuning untuk level pencapaian 3,1 sampai dengan 8, yang berarti pihak manajemen harus lebih berhati-hati karena pencapaian KPI belum tercapai meskipun nilainya sudah mendekati target, terdapat $3 \mathrm{KPI}$ yang berwarna merah untuk level pencapaian 0 sampai dengan 3, yang berarti pencapaian KPI benar-benar jauh dibawa target dan perlu diadakan perbaikan. Indeks pencapaian kinerja keseluruhan RS. Elizabeth Situbondo periode pengukuran tahun 2006 adalah baik dengan skor kinerja sebesar 6,616 berwarna kuning. 


\section{DAFTAR PUSTAKA}

Yuwono, S., 2006. Petunjuk Praktis Penyusunan Balanced Scorecard. Jakarta: Gramedia Pustaka Utama.

Kaplan, R.S., dan Norton, D.P., 2001. Balanced Scorecard, Pengukuran untuk Meningkatkan Kinerja. Jakarta: Gramedia Pustaka Utama.

Gaspersz, V., 2005. Integrasi Balanced Scorecard dan Six Sigma. Jakarta: Gramedia Pustaka Utama

Permadi, S.B., 1992. Analytical Hierarchy Process. Jakarta: Universitas Indonesia.
Saaty, T.L., 1993. Pengambilan Keputusan bagi Para Pemimpin, Proses Analitik untuk Pengambilan Keputusan dalam Situasi yang Kompleks. Jakarta: Pustaka Binaman Prestindo.

Siagian, P., 1987. Penelitian Operasianal, Teori dan Praktek. Jakarta: Universitas Indonesia

Wijono, D., 2000. Manajemen Mutu Pelayanan Kesehatan, Teori, Strategi dan Aplikasi. Surabaya: Airlangga University Press. 